\title{
Priorities Assignment for Information Systems Based on Todim Multicriteria Method
}

\author{
Ana Paula Cabral \\ Seixas Costa \\ Federal University of \\ Pernambuco, Recife, Brazil \\ Daula@chesf.gov.br
}

\author{
Adiel Teixeira de \\ Almeida \\ Federal University of \\ Pernambuco, Recife, Brazil \\ halmeida@npd.ufpe.br
}

\author{
Luiz F. Autran M. Gomes \\ Federal University of \\ Fluminense, Rio de Janeiro, \\ Brazil \\ gpsid@npd.ufpe.br
}

\begin{abstract}
The paper presents how to select modules of an information system, applying a multicriteria decision approach, using the interactive multicriteria decision making method - TODIM. The problem is to assign priorities for information modules in the planning stage of information systems. These priorities should be attributed in agreement with the decision makers' preferences, considering the impact on strategic factors and operational aspects of processes, as examples of criteria.

The TODIM method is based on the prospect theory and has the technical resources to minimise the possibility of occurrence of the reversion order. It also allows the multicriteria decision approach a group of interdependent actions; this method uses the additive difference model to determine the ranking of an alternative over another one.
\end{abstract}

An analytical structure is proposed to incorporate the multicriteria TODIM method, integrated with the information system planning methodology. Strategic factors and operational aspects of processes are integrated.

Keywords: Information systems priorities, TODIM method, Multicriteria decision

\section{Introduction}

In the information system (IS) planning context, some approaches are found in literature on the subject of priorities of information systems (Sprague, 1989). However, ad hoc procedures have only been applied in most cases (Zachman, 1982).

This paper presents the information system planning methodology and the priorities assignment of information systems based on multicriteria aid.

Another multicriteria decision model was proposed to aid prioritising the step in the methodology context to information systems planning.

This approach apply a multicriteria decision aid, and uses the interactive multicriteria decision making method - TODIM

\footnotetext{
Material published as part of these proceedings, either on-line or in print, is copyrighted by Informing Science. Permission to make digital or paper copy of part or all of these works for personal or classroom use is granted without fee provided that the copies are not made or distributed for profit or commercial advantage AND that copies 1) bear this notice in full and 2) give the full citation on the first page. It is permissible to abstract these works so long as credit is given. To copy in all other cases or to republish or to post on a server or to redistribute to lists requires specific permission from the publisher atpublisher@intormingscience.org
}

\section{Information Systems Planning}

The methodology of IS Planning applied in this paper was developed as a result of a previous works (Almeida, 1997) research project in this line. The first stage in methodology of Planning, presented in this paper, consists of a study of the organisation in 
order to obtain its strategic vision. In this stage the strategic factors are obtained (Almeida, 1999a)

From the strategic vision of the business, the Engineering of Business Processes begins. This consists of the definition of all the processes that are developed in the different sections of the studied area. The main goal of the following stage - denominated Engineering of Information - is to underline the architectural construction of the organisation's IS.

The architecture of the IS contemplates the Groupings of Information (AGI) and the diverse Types of technologies (TSI) and tools which can be used for their treatment. The combination of these two visions (AGI and Types of technologies) forms the IS Modules (MSI) This phase of the methodology is composed of three stages: Corporate data, Modulating and Prioritising. MSI's are prioritised, having as their objective the support of the attainment of the organisation's expected results.

The last stage consists of the Plan of Action, which defines the projects to be developed, breaking away from certain priorities and the analysis of the hardware structure, software and the human resources involved.

The methodology applied for Information System Planning is presented in the following summary. Figure 1 presents the development stages for construction of the structure of SI, as previously described.

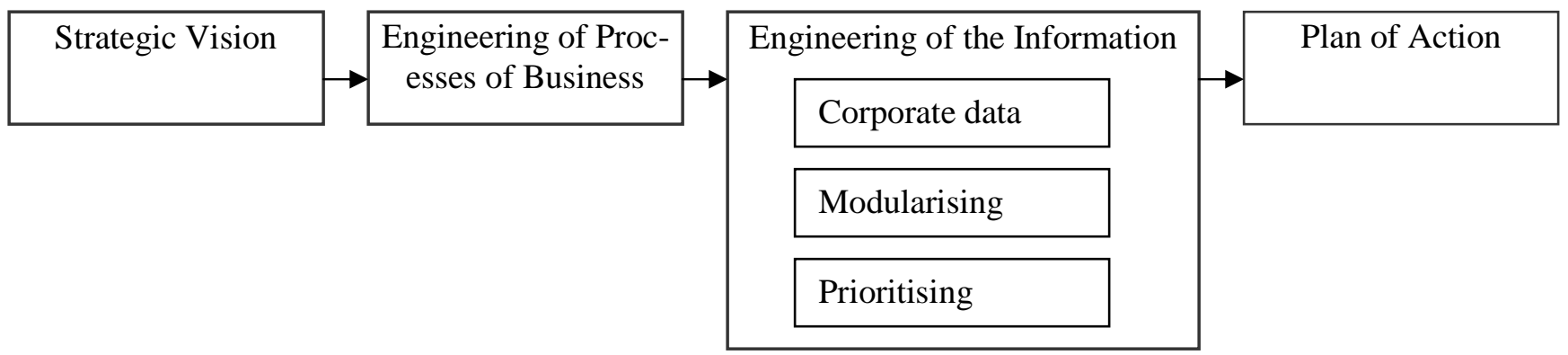

Figure 1 - Methodology for Information Systems Planning

The process of prioritising the MSI is based on the classification of modules through scale criteria. This is to identify the decision-maker's degree of preference for an MSI over another one. It is based on the decision maker's judgement in relation to each criteria, mainly including the vision of the organisation processes, directly associated to the Strategic Administration of the organisation.

The result of the employment decision model for prioritising is obtained directly from the structure of the MSI. The determining of the Information System Modules (MSI) is structured starting from a segmentation matrix form of the two stand points to assemble the information (AGI and TSI). (Almeida, 1999a)

In the first stand point, AGI and TSI assemble information by type; more specifically, they try to segment the information related to processes and also being considered; classes of data. In the case of TSI, the paradigm proposed by Sprague and Watson (1989) is used, considering the three basic criteria for systems of information. The three criteria consist of Transactional Information Systems (TIS), Managerial Information Systems (MIS) and Decision Support Systems (DSS) (Sprague, 1989).

The modularising then consists of crossing each AGI with each TSI, obtaining Information Systems Modules (MSI). This can be represented by a matrix, where an AGI correspond and to each row and a TSI to each column. As a result, the cells correspond to MSI. 


\begin{tabular}{l|l|l|l|l} 
& AGI1 & AGI2 & AGI3 & AGI4 \\
\hline TIS & MSI11 & MSI21 & & MSI41 \\
\hline MIS & MSI12 & & & \\
\hline DSS & & & & \\
\hline EIS & & & & \\
\hline SAE & & & & \\
\hline SAP & & & & \\
\hline SAG & MSI7 & & & MSI44
\end{tabular}

Figure 2 - Representation of the MSI from their corresponding AGI and TSI

In a preliminary stage of the prioritising, the evaluations for MSI are obtained for each criteria. In the shown matrix form above, $\mathrm{m}$ AGI and $\mathrm{r}$ TSI are considered, corresponding to a total of $\mathrm{z}$ MSI, so that $\mathrm{z}=$ m.r.

\section{Interactive Multicriteria Decision Making Method - TODIM}

Introduced by Gomes and Lima (1992), The TODIM method constructs a preference model for risky decisions, in agreement with Prospect Theory base (Kahneman and Tversky, 1979).

This method uses an additive difference function to establish the dominance of an alternative over another one, it is describes one alternative through of one prioritisation of all the alternatives. The risk related with each alternative will be a dimensionless value, once it doesn't favour one objective over of the remaining ones, that is to say, the objective multiples of the decision problem are respected.

The associated partial risks for one specific alternative can be obtained from the specialists' preferences, in the case of the qualitative criteria and by calculations obtained with the quantitative criteria.

The TODIM method is based on a similar notion of the net flow as the Promethee multicriteria method. (Costa, 2001)

The value judgements can be expressed on either a cardinal or a verbal scale.

The additive difference function used to establish the dominance of an alternative over another one is present below:

$\delta(i, j)=\sum_{c=1}^{m} \phi_{c}(i, j) \quad \forall(i, j)$

where: 


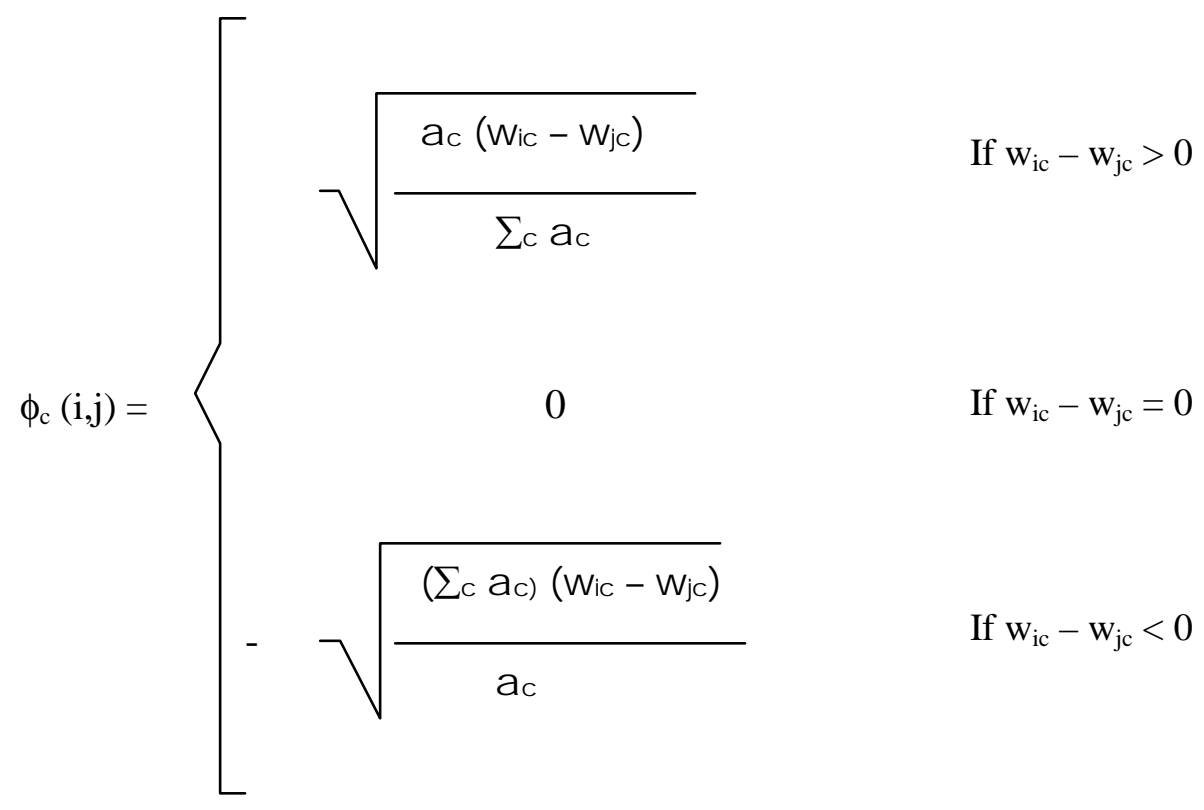

and,

$\mathrm{m}$ - number of criteria ;

$\mathrm{c}-\mathrm{a}$ generic criterion, $\mathrm{c}=1, \ldots, \mathrm{m}$;

ac - the normalized weight of criteria $\mathrm{c}$ by criterion

wic, wjc - evaluation of alternatives $i$ and $j$, with regard to criterion $c$.

It should be noted that wic $-w j c>0$ represents a relative gain, while wic - wjc $<0$ represents a relative loss.

The overall values of the various alternatives are combined so as to produce a rank ordering by computing the following values:

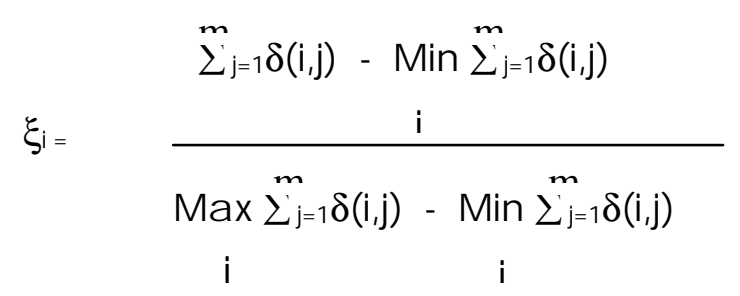

Where: $\xi i$ - overall value of alternative $i$,

$\mathrm{n}$ - number of alternatives

\section{Priorities Assignment of Information Systems and Multicriteria Decision Aid}

To incorporate the multicriteria TODIM method integrated with the information system planning methodology, the decision-maker should provide the scale criteria for intensity of importance for each alterna- 
tive, in agreement with correspondence between verbal and cardinal scales. That is to say, the decisionmaker verbalize his judgement for each of the alternatives and we establish a correspondence with a cardinal scale, and we can do the same for each criteria, as follows:

\begin{tabular}{|c|c|c|}
\hline Alternative X Criteria & Criteria X Criteria & Intensity of Importance \\
\hline $\begin{array}{l}\text { Alternative } i \text { does not contribute } \\
\text { to criteria } c\end{array}$ & - & 0 \\
\hline $\begin{array}{l}\text { Alternative } i \text { has a very weak } \\
\text { importance to criteria } c\end{array}$ & $\begin{array}{l}\text { Criteria } p \text { is equal in importance } \\
\text { to criteria } q\end{array}$ & 1 \\
\hline $\begin{array}{l}\text { The importance of alternative } i \\
\text { is between very small and weak } \\
\text { to criteria } c\end{array}$ & $\begin{array}{l}\text { The importance of criteria } \mathrm{p} \text { is } \\
\text { between equal to an slightly }> \\
\text { that of criteria q }\end{array}$ & 2 \\
\hline $\begin{array}{l}\text { Alternative } i \text { has a weak impor- } \\
\text { tance to criteria } c\end{array}$ & $\begin{array}{l}\text { The importance of criteria } p \text { is } \\
\text { slightly }>\text { that of criteria } q\end{array}$ & 3 \\
\hline $\begin{array}{l}\text { Alternative } i \text { has some impor- } \\
\text { tance to criteria } c\end{array}$ & $\begin{array}{l}\text { Criteria } p \text { is more important than } \\
\text { criteria } q\end{array}$ & 4 \\
\hline $\begin{array}{l}\text { Alternative } i \text { has a strong impor- } \\
\text { tance to criteria } c\end{array}$ & $\begin{array}{l}\text { Criteria } p \text { is much more impor- } \\
\text { tant than criteria } q\end{array}$ & 5 \\
\hline $\begin{array}{l}\text { The importance of alternative } i \\
\text { is between very strong and } \\
\text { strong to criteria } c\end{array}$ & $\begin{array}{l}\text { The importance of } p \text { is between } \\
\text { strongly and very strongly more } \\
\text { important than } q\end{array}$ & 6 \\
\hline $\begin{array}{l}\text { Alternative } i \text { has a very strong } \\
\text { importance to criteria } c\end{array}$ & $\begin{array}{l}\text { Criteria } p \text { is very strongly more } \\
\text { important than criteria } q\end{array}$ & 7 \\
\hline $\begin{array}{l}\text { The importance of alternative } i \\
\text { is between very strong and } \\
\text { absolute to criteria } c\end{array}$ & $\begin{array}{l}\text { The importance of } p \text { is very } \\
\text { strongly and absolutely more } \\
\text { important than } q\end{array}$ & 8 \\
\hline $\begin{array}{l}\text { Alternative } i \text { absolute impor- } \\
\text { tance to criteria } c\end{array}$ & $\begin{array}{l}\text { Criteria } p \text { is absolutely more } \\
\text { important than criteria } q\end{array}$ & 9 \\
\hline
\end{tabular}

Table 1 - Verbal and cardinal scales

The scale from 0 to 9 is used for ordering alternatives with respect to criteria, and the scale from 1 to 9 is employed for relative comparisons between criteria.

The evaluation of each alternative for each criteria, in the systems planning methodology context is obtained from an analytical structure proposed to proceed, considering the prioritising model based on aggregation process (Almeida, 1999a).

Thus, evaluations of MSI for each criteria are obtained and will be represented by a matrix in the following way, considering c criteria, m AGI and r TSI.:

$$
\left\|m_{i j}\right\|=\left[\begin{array}{cccc}
m_{11} & m_{12} & \ldots & a t_{1 c} \\
m_{21} & & & \\
\ldots & & & \\
m_{z 1} & \ldots & \ldots & m_{z c}
\end{array}\right] \text {, }
$$

The Model consists of obtaining a matrix of MSI for each criteria. This matrix is reorganised and presented in the form adapted for evaluation by the multicriteria method. 
Thus, evaluations of MSI for each criteria are obtained and will be represented by matrix a as follows, considering c criteria, m AGI and r TSI.:

$$
\left\|m^{c_{i j}}\right\|=\left[\begin{array}{cccc}
m^{c_{11}} & m^{c_{12}} & \ldots & m^{c_{1 m}} \\
m^{c_{21}} & & & \\
\ldots & & & \\
m^{c}{ }_{r 1} & \ldots & \ldots & m^{c}{ }_{r m}
\end{array}\right] .
$$

Through the methodology of Information Systems Planning, three groups of criteria were defined: Strategic Criteria, Criteria of Processes and Technical Criteria.

The strategic criteria are obtained through the strategic planning, in a higher hierarchical level. The criteria of processes are obtained through evaluations of the processes, in a hierarchical level below the strategic criteria. The technical criteria are also in a lower hierarchical level, related to the types of service of information used. (Almeida, 1999a)

To incorporate the results obtained above in the form adapted for evaluation by multicriteria methods, the vector $\left\|c_{i}\right\|$, representing the relative weight of all criteria and matrix $\left\|m_{i j}\right\|$ will be used, which represents the evaluation of all the $\mathrm{z}$ MSI for all the c criteria.

It should be observed that the columns of main $\left\|m_{i j}\right\|$ represent the evaluation of the group of MSI for each criteria. The rows show MSI, through a combination of AGI and TSI. $\left\|m_{i j}\right\|$ are obtained starting from the group of main $\left\|m^{c} i j\right\|$. Thus, the column c of $\left\|m_{i j}\right\|$ is obtained through matrix $\left\|m^{c} i j\right\|$. That is to say, the values of the column mij correspond to the values of the matrix $\left\|m^{1} i j\right\|$, where the elements are renumbered by column then row. (Almeida,1999a)

Starting from the matrix and vector, the scale criteria for each criteria being defined, a matrix with the intensity of preference for each pair of alternatives $(i, j)$ is obtained for criteria. With the base in the obtained matrix, $\xi \mathrm{i}$ is calculated, establishing the process of classification or ranking of MSI for the method TODIM.

\section{Application}

A case study was developed using a simplified model of a study made in the Telecommunications Department of the São Francisco Hidro Electric Company (CHESF). This company is responsible for generating and managing the transmission of electric energy for the whole Northeast of Brazil. The CHESF Telecommunications Department must provide communication services for all technical, operational and management company areas (Lyra, 2001).

Starting from the results obtained with the matrix, for $c=1, \ldots, 8,(8$ different criteria $)$ the matrix $\left\|m_{i j}\right\|$ is obtained. It was observed that the results just indicate $11 \mathrm{MSI}$, when $\mathrm{z}=12$. This happens because the MSI, which would be relative to the combination of the AGI Administration of Services and Executive 
Information Systems, does not exist, appearing in the results of the matrix as null values. Table 2: Valid MSI.

\begin{tabular}{|c|c|}
\hline MSI & \\
\hline 1 & AGI: Human resources; TSI: TIS \\
\hline 2 & AGI: Human resources; TSI: MIS \\
\hline 3 & AGI: Human resources; TSI: DSS \\
\hline 4 & AGI: Human resources; TSI: EIS \\
\hline 5 & AGI: Services Management; TSI: TIS \\
\hline 6 & AGI: Services Management; TSI: MIS \\
\hline 7 & AGI: Services Management; TSI: DSS \\
\hline 8 & AGI: Financial resources.; TSI: TIS \\
\hline 9 & AGI: Financial resources.; TSI: MIS \\
\hline 10 & AGI: Financial resources.; TSI: DSS \\
\hline 11 & AGI: Financial resources; TSI: EIS \\
\hline
\end{tabular}

Table 2 - Valid MSI

By applying TODIM, we calculate the $\xi \mathrm{i}$, (as previously described), and we obtain the rank of the valid MSI:

\begin{tabular}{|c|c|}
\hline MSI & Rank \\
\hline 1 & 6 \\
\hline 2 & 11 \\
\hline 3 & 7 \\
\hline 4 & 3 \\
\hline 5 & 9 \\
\hline 6 & 5 \\
\hline 7 & 8 \\
\hline 8 & 10 \\
\hline 9 & 4 \\
\hline 10 & 2 \\
\hline 11 & 1 \\
\hline
\end{tabular}

Table 3 - Ranks

In the following stage the priorities assignment in the information systems planning methodology, the Plan of Action will concentrate on the group of prioritized MSI. The concern in a new future, will be with the development projects related to these MSI. Following the ordering, other projects can also be implemented, depending on the availability of funds, as well as of other relative aspects to the projects, such as technical precedent.

\section{Comments}

One of main difficulties in the application of a multricriteria decision aid method is to obtain from the decision-maker the judgement on a set of alternatives and to transform this judgement in an objective evaluation that induces the choice or rank of the best alternatives.

The method TODIM allows obtaining this judgement more easily through the correspondence between the verbal and cardinal scales 
Priorities Assignment for Information Systems

The method TODIM, besides being based on the prospect theory, possesses technical resources to minimize the possibility of occurrence of the reversion of the order and allows the treatment multicriteria of a group of interdependent alternatives, elements that are not usual in most of the methods multicriteria decision aids.

\section{References}

Almeida, A. T. de; Bohoris, G. A.; Steinberg, H.; (1992) Managenment Information and Decision Support System of a Telecomunication Network, Journal of Decision Systems. 1(2-3)pp.213-241.

Almeida, A. T., (1997); Decision Modelling on Planning and Management of Information Systems, EURO XV - INFORMS XXXIV Joint International Meeting; Barcelona, Spain, July 14-17, 1997.

Almeida, A. T. de (1999a); Um Modelo de Decisão para Priorização no Planejamento de Sistemas de Informação, Revista Produção, Vol. 8, n 2, pp. 169-185.

Costa, A.P.C.S., Almeida, A. T. de, (2001), Promethee Multicriteria Aid on Priorities Assignment of Information Systems, IEEE Systems, Man, and Cybernetics Conference.

Elam, P.(1980), Choosing between systems development alternatives, Journal of Systems Management, 31(9):36-40, Sept 1980.

Gomes, L.F. y M. Lima (1992), From modelling individual preferences to multicriteria ranking of discrete alternatives: a look at prospect theory and the additive difference model (Foundations of Computing and Decisions Sciences, vol. 17).

Kahneman, D. , Tversky, A., (1979), Prospect Theory an Analysis of Decisions under Risk, Econometrica 47, 1979,262-291.

Lyra, G., Almeida, A. T. de, Costa, A. P. C. S, (2001)., ELECTRE Multicriteria Aid on Priorities Assignment of Information Systems, Information Resources Managment Association International Conference, Toronto - Canada, May 2001, pp. 681.

Sprague Jr, R. H., Watson, H. J. (Ed) (1989); Decision Support Systems - Putting Theory into Practice, Prentice-Hall, Inc; 1989

Vincke, P.; (1992), Multicriteria decision-aid,. John Wiley \& Sons. ISBN: 0-471-93184-5.

Zachman, J. (1982), A Business systems planning and business information control study, a comparision,. IBM Systems Journal, 21(1): 31-53, 1982.

\section{Biographies}

Ana Paula Cabral Seixas Costa: MSc and doctorate student by Federal University of Pernambuco, Northeast Brazil, she acts in Information Systems and Decision area.

Adiel Teixeira de Almeida: PhD by University of Birmingham, England, titular professor of Federal University of Pernambuco, Northeast Brazil, he acts in the Multicriteria Decision-aid, Information Systems and Performance Evaluation area.

Luiz Flávio Autran Monteiro Gomes: PhD by University of California, Berkeley, USA, post doctorate by University of Stuttgart, Western Germany, titular professor of Federal University Fluminense, Southeast Brazil, he acts in the Operational Research, Transports Planning, Quality Control and Management of Specific Sections area. 